\title{
ANTIBACTERIAL ASSAY OF 2'-HYDROXY-4',6',4-TRIMETHOXYCHALCONE AND 4-METHOXYCHALCONE AGAINST GRAM POSITIVE AND GRAM NEGATIVE BACTERIA
}

\author{
${\text { Wiwit Sepvianti }{ }^{\mathrm{a}^{*}} \text {; Serafica Btari Christiyani Kusumaningrum }}^{\mathrm{b}}$ \\ a,b STIKES Guna Bangsa Yogyakarta ; Ringroad Utara ; Sleman 55283 ; Indonesia
}

\begin{abstract}
Blood transfusion is currently one of the most important health care treatments. Unfortunately, the prevalence of transfusion reactions caused by the use of blood products is still quite high although blood products have been tested in terms of infectious diseases using 4 parameters, namely hepatitis B, hepatitis C, HIV and syphilis. The results of the analysis of blood products produced by UTD (Blood Transfusion Unit) Surabaya showed bacterial contamination of blood products, starting from normal skin flora to pathogens. Bacterial contamination is also believed to be one of the causes of transfusion reactions. Therefore, it is necessary to make efforts to prevent bacterial contamination of blood products. One of the efforts is to find chemical compounds that have good antibacterial activity. In this study, the antibacterial activity of 2 ' -hydroxy-4 ', 6 ', 4-trimethoxychalcone and 4-methoxychalcone was tested against gram positive and gram negative bacteria. The test method was agar diffusion at various concentrations of chalcone, namely $0.625 ; 1.25 ; 2.5$ and $5.0 \%$. The results showed that both chalcones had good antibacterial activity against gram-positive and gram-negative bacteria.
\end{abstract}

Keywords: chalcone ; antibacterial activity ; gram positive ; gram negative

\section{Introduction}

The use of various blood products such as whole blood; packed red cells or thrombocyte concentrate as drug preparations has increased over year (Darmawan and Irawan, 2015). Blood transfusions are performed in various medical conditions such as chronic anemia, blood loss (Thalassemia, Hemophilia, Leukemia and Thrombocytopenia) and massive bleeding (trauma, surgical processes, DIC, GI bleeding and baby delivery (Booth et al., 2017). The vital role of blood transfusions in clinical practice is inseparable from various risks such as acute hemolytic, bacterial infection, acute lung injury, accumulation of interstitial fluid in the lungs, severe allergic reactions and anaphylaxis (Delaney et al., 2016). Analysis of bacteria in blood products may reduce transfusion risks due to bacterial contamination (Kusumaningrum and Sepvianti, 2018).

\footnotetext{
*) Corresponding Author (Wiwit Sepvianti)
}

E-mail: wiwit.sepvianti01@gmail.com
The results of blood product analysis carried out at UTD (Blood Transfusion Unit) of PMI (Red Cross) Surabaya showed bacterial contamination in various blood products such as whole blood and thrombocyte concentrate. Some of the species of the bacterial contaminants found are: Sphingomonaspaucimobilis; Propionibacterium acnes; Staphylococcus hominis;

Fusobacteriumvarium;Prophyromonasassacchar olytica; and Staphylococcus aureus (Tjiptoprajitno et al, 2012). In addition, another study found Escherichia coli in whole blood (Alizadeh et al, 2017). Bacterial contaminants consist of both gram positive and gram negative. Besides, most of the bacteria are normal skin flora and pathogens such as Staphylococcus aureus and Escherichia coli.

Based on such description, it is understandable that currently efforts shall be made to prevent bacterial infections in blood products. One of the efforts that can be made is to find chemical compounds that have good 
antibacterial activity. One compound that is often reported to have good biological activity is chalcone (Sepvianti, 2016). This study tested the antibacterial activity of 2 ' -hydroxy-4 ', 6 ',4-trimethoxychalcone and 4-methoxychalcone against gram positive bacteria (Staphylococcus aureus) and gram negative ones (Escherichia coli).

\section{Method}

The antibacterial activity of 2'-hydroxy-4',6',4-trimethoxychalcone and 4-methoxychalcone was tested using agar diffusion method by measuring the clear zone which indicates the inhibitory power of the compounds. The bacteria used were Escherichia coli (Gram Negative) and Staphylococcus aureus (Gram Positive). The method to test the antibacterial activity referred to Setyawati, et al (2017).

\section{Materials}

2'-hydroxy-4',6',4-trimethoxychalcone,4-me thoxychalcone, nutrient broth, distilled water, agar, 70\% alcohol, Brain-Heart Infusion (BHI), antibiotics, DMSO, culture of gram positive bacteria Staphylococcus aureus ATCC, and culture of gram negative bacteria Escherichia coli ATCC.

\section{Making solution to test chalcone}

The test solution was made by dissolving chalcone in DMSO at various concentrations, namely $0.625 ; 1.25 ; 2.5$ and $5 \%$.

\section{Sterilizing equipment}

The equipment was sterilized using an autoclave at a temperature of $121^{\circ} \mathrm{C}$ under a pressure of 15 atm for 15 minutes. Equipment which could not be heat-sterilized was sterilized using $70 \%$ alcohol.

\section{Making agar base}

$2.8 \mathrm{~g}$ of nutrient broth powder was dissolved in distilled water until the volume was $100 \mathrm{~mL}$. The solution was heated until the powder was completely dissolved, then sterilized using autoclave.

\section{Bacterial rejuvenation}

A total of $0.24 \mathrm{~g}$ of nutrient broth was dissolved in $30 \mathrm{~mL}$ of distilled water. The solution was then poured into 5 reaction tubes; each of the tubes contained $6 \mathrm{~mL}$ of $\mathrm{NB}$ solution.
Afterwards, they were sterilized using an autoclave at a temperature of $121^{\circ} \mathrm{C}$ under a pressure of $15 \mathrm{~atm}$ for 15 minutes. Each of the tubes was filled with $3 \mathrm{~mL}$ of Staphylococcus aureus and Escherichia coli, then incubated at $37^{\circ} \mathrm{C}$ for 24 hours.

\section{Making bacterial media}

Each petri dish was filled with $1000 \mu \mathrm{L}$ Staphylococcus aureus and Escherichia coli resulted from the bacterial rejuvenation. The agar solution was poured into the petri dish which had been filled with the media base and a ring was put on it. The petri dish was then covered and left for some time. The ring was removed when the agar had solidified, so an agar well was formed.

\section{Sample injection and measurement of inhibition zone}

$25 \mu \mathrm{L}$ of the test samples at concentrations of $0.625 ; 1.25 ; 2.5$ and $5 \%$ was poured into the well. The positive control was chloramphenicol and the negative one was DMSO. Incubation was carried out for 24 hours, followed by measurement of inhibition zone. The diameter of the inhibition zone was measured using a caliper to determine antibacterial activity.

\section{Result and Discussion}

Both of these compounds were dissolved in DMSO at various concentrations, namely 0.625 ; $1.25 ; 2.5$ and $5.0 \%$. In addition to functioning as solvent, DMSO also served as the negative control, while chloramphenicol as the positive control. The bacteria used for the test were Staphylococcus aureus ATCC (Gram Positive) and Escherichia coli ATCC (Gram negative), both of which were pathogens which were reported to contaminate blood products. The results of the antibacterial activity test on 2'-hydroxy-4',6',4-trimethoxychalcone and 4-methoxychalcone are presented in Table 1.

Tabel 1. Antibacterial Data Of Chalcone

\begin{tabular}{|c|c|c|c|c|}
\hline \multirow{3}{*}{$\begin{array}{l}\text { Conc. } \\
(\%)\end{array}$} & \multicolumn{4}{|c|}{ Zone of inhibition (mm) } \\
\hline & \multicolumn{2}{|c|}{$\begin{array}{l}\text { 2'-hydroxy-4',6',4- } \\
\text { trimethoxychalcone }\end{array}$} & \multicolumn{2}{|c|}{$\begin{array}{c}4- \\
\text { methoxychalcone }\end{array}$} \\
\hline & S.aureus & E.coli & S.aureus & E.coli \\
\hline 0.625 & 2.7 & 0.1 & 5.3 & 0.5 \\
\hline 1.25 & 2.4 & 0.8 & 9.1 & 1.1 \\
\hline 2.5 & 4.6 & 2.2 & 5.7 & 1.6 \\
\hline 5.0 & 8.0 & 14.0 & 6.3 & 10.0 \\
\hline $\begin{array}{c}\text { Control } \\
(+)\end{array}$ & 18.0 & 13.0 & 18.0 & 13.0 \\
\hline $\begin{array}{c}\text { Control } \\
(-)\end{array}$ & - & - & - & - \\
\hline
\end{tabular}


A compound is stated to be an antibacterial agent if it has an inhibition zone greater than 6.0 mm (Sepvianti and Kusumaningrum, 2019). In this study, both chalcones showed good antibacterial activity with inhibition zones greater than $6.0 \mathrm{~mm}$ at certain concentrations.

2'-hydroxy-4',6',4-trimethoxychalcone had good inhibitory power at a concentration of $5.0 \%$ with an inhibition zone diameter greater than 6.0 $\mathrm{mm}$, i.e. $8.0 \mathrm{~mm}$ on Staphylococcus aureus and $14.0 \mathrm{~mm}$ on Escherichia coli. The inhibitory power shown by 2'-hydroxy-4',6',4-trimethoxychalcone against Escherichia coli was far better than that by the antibiotic control, with a difference in the inhibition zone diameter of $1.0 \mathrm{~mm}$.

4-methoxychalcone also showed similar results: at a concentration of $5.0 \%$ this compound had a diameter of inhibition zone greater than $6.0 \mathrm{~mm}$, i.e. $6.3 \mathrm{~mm}$ on Staphylococcus aureus and $10.0 \mathrm{~mm}$ on Escherichia coli. In addition, at a concentration of $1.25 \%$ this compound showed greater inhibitory power, i.e. $9.1 \mathrm{~mm}$, against Staphylococcus aureus.

Based on these observations, 2'-hydroxy-4',6',4-trimethoxychalcone had larger inhibition zone compared to 4-methoxychalcone. This is supposedly due to differences in the types and number of functional groups bound to these two compounds. 2'-hydroxy-4',6',4-trimethoxychalcone bound hydroxyl and methoxy groups in ring $\mathrm{A}$ and ring $\mathrm{B}$, while 4-methoxychalcone only had methoxy group in Ring B. The structure of chalcones is shown in Figure 1.

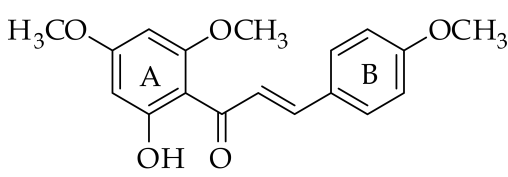

2'-hyd roxy-4',6',4-trimethoxychalcone<smiles>COc1ccc(/C=C/C(=O)c2ccccc2)cc1</smiles>

Figure 1. Structure of Chalcone

Both chalcones had methoxy bound to these two groups which had been reported as an active antibacterial compound. Nonetheless, only 2'-hydroxy-4',6',4-trimethoxychalcone had hydroxyl in Ring A. This group was thought to increase the antibacterial activity of 2'-hydroxy-4',6',4-trimethoxychalcone because hydroxyl group is known to have the ability to dissolve lipids in the outer membranes of gram negative bacteria which then damages membranes, thus disrupting bacterial defense.

\section{Conclusion and Suggestion}

It can be concluded that 2 ' -hydroxy-4 ', 6 ,4-trimethoxychalcone and 4-methoxchalcone have good antibacterial activity against gram positive bacteria (Staphylococcus aureus) and gram negative bacteria (Escherichia coli). Both compounds have the potential to be developed as antibacterial compounds.

\section{Acknowledgements}

Our gratitude goes to the Ministry of Research, Technology, and Higher Education of the Republic of Indonesia for providing Research Grant with contract number B/1435.37/L5/RA.00/2019.

\section{References}

Alizadeh, M., Wood, R.L, Buchanan, C.M., Bledsoe, C.G. (2017). Rapid separation of bacteria from Blood- Chemical Aspects, Colloids and surfaces B:Biointerface. 154: 365-372.

Booth C., and Allard, S.. (2017). Blood Transfusion. Medicine. 46. 244-250.

Darmawan, A., Irawan, R. (2015). Mengenal CPOB untuk Produk Darah. JMJ. 3:111-118.

Delaney M., Wendel S., Bercivitz R., Cid J, Cohn C.,Dunbar N.M. (2016). Transfusion Reactions: Prevention Diagnosis and Treatment. 388. 2824-2836.

Kusumaningrum, S. B. C., and Sepvianti, W. (2018, Desember). Analisis Produk Darah: Kontaminasi Bakteri Pada Thrombocyte Concentrate.

Sepvianti, W., (2016). Sintesis dan Uji Sitotoksisitas Turunan Kalkon terhadap Sel Kanker T47D, Hela dan WiDr secara In Vitro. Thesis, Pasca Sarjana. Universitas Gadjah Mada.

Setyawati, A., Wahyuningsih, T,D., Purwono, B. (2017, October). Novel Pyrazolines as Antibacterial Agents from Natural Product Vanilin. Asian Journal of Chemistry.29. $454-456$

Sepvianti, W. and Kusumaningrum, S. B.C. (2019, January). Aktivitas Antibakteri Senyawa 
Jurnal Riset Kesehatan, 8 (2), 2019, 20 - 20

DOI: $10.31983 /$ jrk.v8i2.5378

2'-hidroksi-4',6'-dimetoksikalkon. Journal of Health.(6). 37-39.

Tjiptoprajitno, N.A., Aryanti, Sudiana, I.K. (2012).

Analisis Produk Darah Thrombocyte Concentrate di Palang Merah Indonesia Surabaya. JBP. 14, 145-152. 